\title{
As vilas na América portuguesa e a emergência da instrução pública (séculos XVIII e XIX)
}

\section{(Villages in Portuguese America and the Emergence of Public Education in the 18th and 19th Centuries)}

\author{
Thais FONSECA \\ Universidade Federal de Minas Gerais, Brasil
}

\begin{abstract}
RESUMO: As reformas pombalinas da educação tiveram impacto diferenciado nas diversas capitanias da América portuguesa devido às condições locais relacionadas, principalmente, à presença ou ausência da Companhia de Jesus e de outras ordens religiosas. Na Capitania de Minas Gerais a proibição da instalação dessas ordens religiosas, desde o inicio do século XVIII, permitiu à população local, conforme sua qualidade e condição, buscar formas particulares para a educação de seus filhos e dependentes. A criação do ensino régio, a partir de 1759, associada em 1772 à imposição do seu meio de financiamento - o subsidio literário - trouxe novas perspectivas mas também conflitos, que interpuseram o poder local e seus representantes, os professores régios e a Coroa. As aulas régias, primeira experiência concreta da escola pública estatal na região, emergiram como valor e como aparato, também, de poder, na medição das forças políticas e sociais. Este artigo tem como objetivo analisar essas relações a partir da atuação dos principais agentes municipais, dos professores régios e do poder central, no processo de construção do lugar social da escola pública no espaço urbano colonial da região das Minas.
\end{abstract}

PALAVRAS-CHAVE: reformas pombalinas; ensino régio; poder local; câmaras municipais; Brasil.

ABSTRACT: The Pombaline education reforms varied in impact in the different captaincies of Portuguese America depending on local conditions arising mainly from the presence or absence of the Society of Jesus and other religious orders. In the Captaincy of Minas Gerais, the prohibition of the installation of the Jesuits and others at the beginning of the eighteenth century left the local population the freedom to find their own ways of educating their children and dependents, according to their status and condition. The creation of royal education in 1759 and the compulsory system of financing (the so-called 'literary subsidy') introduced in 1772 opened up new perspectives but also conflicts between local rulers, royal teachers and the Crown. Royal education, the first real experience of public education in the region, emerged as a mark and a measurement of political and social power. The aim of this article is to analyse these relationships based on the actions of local leaders, royal teachers and the power of the state in the process of construction of public schools as a social space in the colonial towns of the Minas region.

KEYWORDS: Pombaline reforms; royal education; local power; local government; Brazil. 
Extensa discussão sobre a natureza das reformas pombalinas tem ocupado os historiadores da educação há muitas décadas. Parte deles oscila entre a condenação sumária das reformas e a sua exaltação; outra parte se divide entre colocar as reformas na origem do sistema escolar estatal luso americano, ou vê-las como uma experiência mal sucedida de estabelecimento do Estado como agente da instrução pública. Há, ainda, controvérsias acerca da relação das reformas da educação em Portugal e o pensamento ilustrado1. Tantas questões dão ao tema fôlego suficiente para o aprofundamento das pesquisas e a renovação da análise, e isso é tanto mais pertinente quando se trata da América portuguesa, sobre a qual os estudos tem sido retomados com maior empenho.

O conjunto de ações empreendidas no reinado de D. José I sob o comando do futuro Marquês de Pombal - e que seria, em alguma medida, continuado nos reinados seguintes, de D. Maria I e D. João VI - relacionava-se aos projetos modernizadores da Coroa portuguesa, que incluíam o processo de secularização da administração. Isso significava reduzir sensivelmente as ingerências da Igreja nos negócios do Estado, no Reino e em seus domínios. As reformas da educação, dos estudos menores à Universidade de Coimbra, foram uma clara expressão desses propósitos, começando pela expulsão da Companhia de Jesus, o fechamento de suas escolas e a proibição de seus métodos em todos os territórios portugueses. Como é sabido, os ataques aos jesuítas não significavam ataques à Igreja católica, e integrantes de outras ordens religiosas foram convocados para integrar as novas estruturas administrativas que cuidariam do gerenciamento do ensino régio, criado a partir de $1759^{2}$, mas estariam submetidas a um controle cada vez mais estreito por parte da Coroa e de seus agentes temporais.

A criação da Diretoria Geral dos Estudos pelo mesmo Alvará de 28 de junho, deu início a um processo de contínua centralização da administração do recém-criado ensino régio, como parte da política pombalina de fortalecimento do poder central. Cabia ao rei a nomeação do Diretor Geral, indicando claramente o lugar do ensino na hierarquia administrativa, e a proximidade da Coroa dos assuntos da educação. A Diretoria Geral, no entanto, teria servido para gerenciar apenas o ensino preparatório para os estudos maiores, e no início da década de 1770, uma mudança era preparada a fim de colocar todos os estudos sob o controle de apenas um órgão administrativo. ${ }^{3}$ Foi assim que se extinguiu a Diretoria,

\footnotetext{
${ }^{1}$ Alguns dos autores mais representativos dessas tendências: Laerte Ramos de Carvalho, As reformas pombalinas da instrução pública (São Paulo: Saraiva/Edusp, 1978); Antonio Alberto Banha de Andrade, A reforma pombalina dos estudos secundários no Brasil (São Paulo: Saraiva/Edusp, 1978); Rómulo de Carvalho, História do Ensino em Portugal (Lisboa: Fundação Calouste Gulbenkian, 2008; Fernando de Azevedo, A cultura brasileira (Brasília: Editora da Universidade de Brasília, 1963); Ana Cristina Araújo, O Marquês de Pombal e a Universidade (Coimbra: Imprensa da Universidade de Coimbra, 2014; Ana Cristina Araújo, A cultura das luzes em Portugal (Lisboa: Livros Horizonte, 2003); Carlota Boto, Instrução pública e projeto civilizador. O século XVIII como intérprete da ciência, da infância e da escola (São Paulo: Editora Unesp, 2017); Kenneth Maxwell, Marquês de Pombal, paradoxo do lluminismo (Rio de Janeiro: Paz e Terra, 1996).

${ }^{2}$ Alvará de Regulamento dos Estudos Menores, de 28 de junho de 1759, disponível em http://www. governodosoutros.ics.ul.pt/

${ }^{3}$ Ver análise em: Áurea Adão, Estado absoluto e ensino das primeiras letras. As escolas régias, 1772-1794 (Lisboa: Fundação Calouste Gulbenkian, 1997).
} 
e todo o conjunto dos estudos foi colocado sob o controle da Real Mesa Censória, em $1771^{4}$. As iniciativas para o refinamento do controle central sobre o ensino régio se seguiram com a substituição daquele órgão pela Real Mesa da Comissão Geral sobre o Exame e Censura dos Livros (1787) e que logo passaria a integrar a estrutura da Universidade de Coimbra (1791). A partir de 1794, enfim, a Universidade abrigaria a Junta da Diretoria Geral dos Estudos.

Todo esse processo afetou, também, o papel do poder local nas questões da instrução pública 5 . Até a criação do ensino régio, as câmaras apareciam como principais instâncias de financiamento e gerenciamento da instrução fora do âmbito privado e eclesiástico. $\mathrm{Na}$ América portuguesa elas foram muitas vezes chamadas a assumir essa posição, pagando mestres para o ensino dos meninos, ou pessoas que cuidavam da criação e da educação de crianças expostas e órfãs pobres. No contexto das reformas pombalinas, antes da criação do Subsidio Literário em 1772, as câmaras na América portuguesa ainda tinham a responsabilidade pelo financiamento do ensino régio, pois em geral o pagamento dos mestres era feito com os rendimentos municipais. As medidas tomadas pela Coroa - criação do Subsídio e ampliação do ensino régio pela criação das cadeiras de primeiras letras, e aumento do número também das demais pela Lei de 6 de novembro de 1772 - colocou o poder local diante da política de centralização, mas não tirou dele todas as atribuições relativas à instrução pública.

A Lei havia criado para a América portuguesa 44 cadeiras em diferentes capitanias. Nas Minas Gerais foram criadas sete nas principais vilas: quatro de Primeiras Letras (nas vilas de Sabará, Vila Rica, São João del Rei e na Cidade de Mariana) e três de Gramática Latina (nas vilas de São João del Rei, Vila Rica e na Cidade de Mariana). Logo outras viriam, muitas vezes pelas demandas apresentadas pelos poderes locais. Em 1814 já havia o registro de 46 cadeiras na Capitania, 34 de Primeiras Letras e 12 de Gramática Latina ${ }^{6}$. O mesmo processo ocorria, com algumas especificidades, em outras capitanias do Brasil ${ }^{7}$. Em muitas localidades da atual região nordeste, onde a Companhia de Jesus tinha se

\footnotetext{
${ }^{4}$ Alvará de 4 de Junho de 1771, pelo qual se commette à Real Meza Censoria toda a Administração, e Direcção dos Estudos das Escolas menores deste Reinos, e seus Domínios, disponível em http://www.governodosoutros. ics.ul.pt/

${ }^{5}$ Não obstante a definição do «público» para aquele período histórico estivesse mais próximo de ser «aberto ao público", mesmo que fosse privado, adotamos aqui essa denominação como indicando ser "estatal», uma vez que estamos tratando do processo de escolarização tendo o Estado como principal agente.

6 "Dados sobre a instrucção pública, 1814", Revista do Arquivo Público Mineiro, v.VII, n. II-IV (1902): 989.

${ }^{7}$ Trabalhos importantes sobre o tema, relativamente a outras capitanias do Brasil: Myriam Xavier Fragoso, "O ensino régio na Capitania de São Paulo, 1759-1801" (Tese de Doutoramento), Universidade de São Paulo, 1972; Tereza Maria Rolo Fachada Levy Cardoso, As luzes da educação: fundamentos, raízes históricas e prática das aulas régias no Rio de Janeiro, 1759-1834 (Bragança Paulista, SP: Editora da Universidade São Francisco, 2002); José Carlos de Araújo Silva. "As aulas régias na Capitania da Bahia (1759-1827): pensamento, vida e trabalho de "nobres" professores" (Tese de Doutoramento, Universidade Federal do Rio Grande do Norte, 2006); Adriana Maria Paulo da Silva, Processos de construção das práticas de escolarização em Pernambuco em fins do século XVIII e primeira metade do século XIX (Recife: Editora da UFPE, 2008); Nileide Souza Dourado, "Práticas Educativas Culturais e Escolarização na capitania de Mato Grosso, 1748-1822" (Tese de Doutoramento, Universidade Federal de Mato Grosso, 2014)
} 
estabelecido e se tornado uma referência educacional, as populações esperavam que a responsabilidade pela instrução fosse transferida para outras ordens religiosas, mesmo no contexto da implantação das aulas régias.

A criação dessas aulas, pela Lei de 6 de novembro de 1772, obedeceria a critérios de densidade populacional e localização, "em cada uma das Comarcas, e das Cidades, e Vilas delas, que podem constituir uns Centros, nos quais os Meninos, e Estudantes das Povoações circunvizinhas possam ir com facilidade instruir-se» ${ }^{8}$. Temse, portanto, a conjunção de duas situações que importa considerar: a localização das aulas régias nas áreas de maior concentração populacional, e onde também estaria concentrada a arrecadação do tributo. Assim como no Reino e em outras partes do Brasil, na Capitania de Minas Gerais veremos a geografia do ensino régio acompanhar esses dois movimentos, dado importante quando se pretende analisar aspectos da atuação política do poder local - especificamente das câmaras - nas questões concernentes à implantação da instrução pública estatal. Nesta Capitania, mais urbanizada, estes são elementos de destacada importância para a compreensão dos impactos das políticas desenvolvidas a partir das reformas pombalinas não somente como expressões do processo de centralização e fortalecimento do poder da monarquia, como também da progressiva presença da educação de tipo escolar na sociedade colonial e de sua elaboração como um valor social. Por isso, sua inserção no cenário urbano foi fundamental para este processo.

A Capitania de Minas Gerais foi uma área de ocupação relativamente tardia durante o período da dominação portuguesa; concentrou, para os padrões da época, uma considerável população vivendo em núcleos urbanos; apresentava uma vasta população escrava e liberta; concentrava uma nada desprezível estrutura administrativa civil, eclesiástica e militar. A descoberta do ouro, na última década do século XVII, marcou o processo de ocupação daquele território então chamado genericamente de sertão, e o fluxo populacional decorrente da corrida do ouro, ocorrida nas primeiras décadas do século XVIII, resultou na constituição da capitania mais densamente urbanizada e povoada da América portuguesa. A fim de estabelecer a presença da Coroa sobre o território e controlar os conflitos surgidos nos primeiros tempos da ocupação, a região das Minas foi colocada primeiramente sob a jurisdição da Capitania de São Paulo, e só em 1720 foi criada como capitania separada e com governo próprio 9 .

Até meados do século XVIII, um grande contingente da população das Minas não teria, em nenhum momento da vida, qualquer oportunidade de acesso à educação escolar, e esta situação devia-se, primeiramente, por ser constituída em grande parte

\footnotetext{
${ }^{8}$ Arquivo Público Mineiro/Secretaria de Governo da Capitania/Seção Colonial. SC-394, fls. 47-47a.

${ }^{9}$ Sobre esses temas ver, entre outros: Laura de Mello e Souza, Desclassificados do ouro. A pobreza mineira no século XVIII (Rio de Janeiro: Graal, 1982); Marco Antonio Silveira, O universo do indistinto. Estado e sociedade nas Minas setecentistas, 1735-1808 (São Paulo: Hucitec, 1997); Francisco Eduardo de Andrade, A invenção das Minas Gerais. Empresas, descobrimentos e entradas nos sertóes do ouro na América portuguesa (Belo Horizonte: Autêntica, 2008); Cláudia Damasceno Fonseca, Arraiais e vilas d'el Rei. Espaço e poder nas Minas setecentistas (Belo Horizonte: Editora UFMG, 2011).
} 
por escravos, mas também pela inexistência das instituições mantidas pelas ordens religiosas, proibidas de se instalarem na Capitania desde $1711^{10}$. Raramente, conforme as informações disponíveis nas fontes, as câmaras de algumas vilas pagavam mestres que ensinassem sem custos para as famílias. Os segmentos médios e as elites locais estabeleceram a prática da contratação de mestres particulares, continuada mesmo após a chegada das aulas régias. É entre esses grupos sociais que verifica-se a ocorrência da instrução de natureza escolar nos espaços rurais e mais distanciados das povoações principais, fossem vilas ou arraiais. Essas práticas no âmbito privado tinham relação com a presença de crianças e jovens de maiores posses vivendo em sítios e fazendas, o que tornava o deslocamento até os locais de funcionamento das aulas régias dispendioso ou simplesmente exaustivo.

São poucas as evidências de que, na Capitania de Minas Gerais, tenha sido instalada alguma aula régia de Primeiras Letras ou de Gramática Latina antes das Leis de 1772, que instituíram o Subsídio Literário e que criaram novas cadeiras em todo o Império português. Das cadeiras criadas naquele momento, somente temos registro do funcionamento efetivo, antes de 1780, das de Gramática Latina de Vila Rica e de São João del Rei. Entre 1780 e 1787 algumas aulas aparecem pela primeira vez em seis outras localidades: nas vilas de Sabará, do Príncipe, Pitangui, São José do Rio das Mortes, no arraial de Guarapiranga e na Cidade de Mariana. Quanto às aulas de Primeiras Letras, os primeiros registros situam-se entre 1787 e 1789, isto é, num espaço de dois anos, começaram a funcionar 19 aulas na Capitania. Muito embora essas informações possam vir a ser contestadas à medida que novas fontes são trazidas à luz, é significativo que em uma década tenha havido um aumento considerável do número de cadeiras em funcionamento - mesmo que com eventuais interrupções - e que sua localização tenha coberto uma extensão representativa da ocupação daquele território. E, mais ainda, que 12 dessas cadeiras de Primeiras Letras estivessem situadas em arraiais, jurídica e administrativamente subordinados a algumas vilas, mas não raro bastante populosos. Cabe aqui chamar a atenção para a fração de território onde se concentraram essas aulas régias, situadas numa área relativamente pequena que cobria um raio de pouco mais de $250 \mathrm{~km}$, conforme se vê no mapa abaixo.

Em 1800 o Governador da Capitania de Minas Gerais apresentou um levantamento das cadeiras: havia cinco de Gramática Latina e 16 de Primeiras Letras em atividade, e no rol das cadeiras vagas havia 17 de Primeiras Letras e sete de Gramática Latina, o que totalizaria 45 cadeiras, um número expressivo, praticamente o mesmo do total criado para todo o Brasil pela Lei de 1772. O processo de criação dessas cadeiras depois da referida Lei nem sempre é muito claro. Há evidências de que algumas devessem sua existência aos pedidos feitos pelas populações por intermédio das câmaras municipais, movidas pelas queixas do não cumprimento da Lei, ou seja, pagava-se o Subsidio Literário mas não havia a criação de aulas. É curioso que a Lei não estabelecia essa relação de forma tão bem definida e direcionada, isto é, não afirmava que, em cada localidade onde se

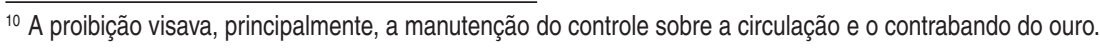


recolheria o tributo haveria a contrapartida de instalação de uma cadeira ${ }^{11}$. Essa relação era mencionada no texto legal de maneira genérica, mas foi certamente interpretada de forma literal pelos interesses locais gerando um argumento que dificilmente poderia ser contestado pela Coroa, o que indica um tipo de prática recorrente nas relações políticas e administrativas entre o poder central e as esferas a ele subordinadas na América: a possibilidade de alguma negociação, ainda que fundamentada na lei, «para que o bem comum fosse estabelecido» ${ }^{12}$, caracterizando o que Laura de Mello e Souza chamou de "prática política pendular» ${ }^{13}$.

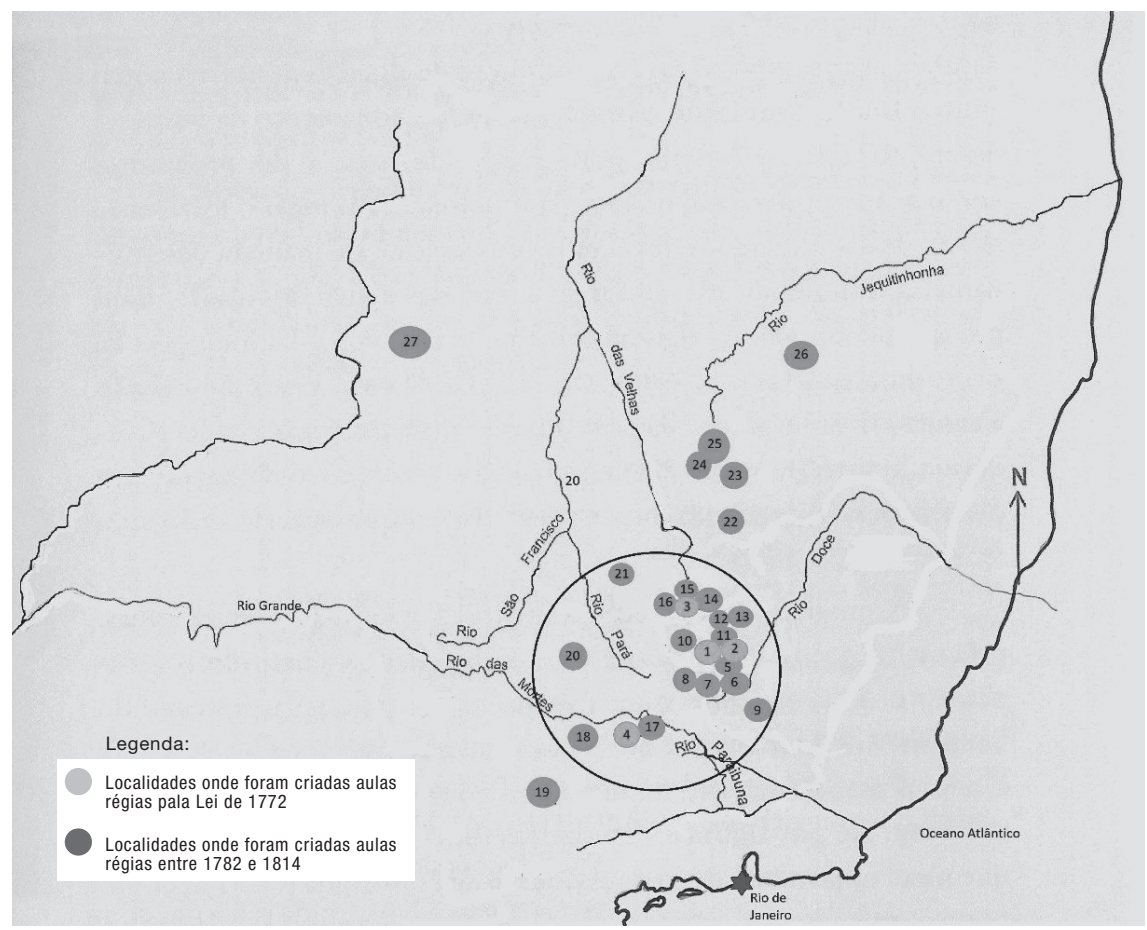

Mapa 1: Localidades da Capitania de Minas Gerais onde foram criadas aulas régias entre 1772 e 1814.

\footnotetext{
${ }^{11}$ Carta de Lei de 10 de Novembro de 1772 e Instrucções de 4 de Setembro de 1773. Disponível em http://www. governodosoutros.ics.ul.pt/

${ }^{12}$ Pablo Menezes e Oliveira, "Entre cartas, panos, tintas e coração: representação e prática política das Casas de Câmara na Capitania de Minas Gerais, século XVIII", In As Minas e o Império: dinâmicas locais e projetos coloniais portugueses, org. Adriano Toledo Paiva e Pablo Menezes e Oliveira (Belo Horizonte: Fino Traço, 2013), 161.

${ }^{13}$ Laura de Mello e Souza, O sol e a sombra. Política e administração na América portuguesa do século XVIII (São Paulo: Companhia das Letras, 2006), 15.
} 
Tabela 1

\begin{tabular}{|c|c|}
\hline 1 & Vila Rica $(1711)^{*}$ \\
\hline 2 & Cidade de Mariana (1711) \\
\hline 3 & Vila de Sabará (1711) \\
\hline 4 & Vila de São João del Rei (1713) \\
\hline 5 & Congonhas do Campo \\
\hline 6 & Arraial de Guarapiranga \\
\hline 7 & Itaverava \\
\hline 8 & Vila de Queluz (1790) \\
\hline 9 & Pomba \\
\hline 10 & Inficionado \\
\hline 11 & Catas Altas \\
\hline 12 & Santa Bárbara \\
\hline 13 & São Miguel \\
\hline 14 & Vila Nova da Rainha (1714) \\
\hline 15 & Santa Luzia \\
\hline 16 & Curral del Rei \\
\hline 17 & Vila de São José (1718) \\
\hline 18 & Santana das Lavras do Funil \\
\hline 19 & Campanha do Rio Verde (1798) \\
\hline 20 & Vila de São Bento do Tamanduá (1789) \\
\hline 21 & Vila de Pitangui (1715) \\
\hline 22 & Conceição do Mato Dentro \\
\hline 23 & Vila do Príncipe (1714) \\
\hline 24 & Gouveia \\
\hline 25 & Arraial do Tejuco \\
\hline 26 & Vila de Minas Novas (1730) \\
\hline 27 & Vila de Paracatu (1798) \\
\hline
\end{tabular}

* As datas entre parênteses indicam o ano da elevação da localidade a vila, durante o período colonial.

A questão do tributo era tema recorrente na correspondência entre as câmaras e as autoridades superiores, mas vinha acompanhada de outros, que expressavam as experiências cotidianas dos problemas locais. Muitas vezes eram esses problemas que acabavam por orientar as ações da administração central, sensíveis, até certo ponto, a essas especificidades que afetavam o funcionamento do ensino régio. Muitas municipalidades queixavam-se de dificuldades no processo de arrecadação do Subsídio Literário, advindas 
dos conflitos entre os produtores e negociantes de aguardente, e os cobradores enviados pelas câmaras. Sem meios de se impor, solicitavam ao governo da Capitania o uso das forças militares para solucionar o problema, sem o que o pagamento dos professores régios ficaria em prejuízo. Outros problemas eram relatados, como as distâncias entre as diversas localidades, aspecto dificultador dos deslocamentos dos estudantes para os lugares onde havia aulas régias em atividade.

As determinações para a criação das aulas nos lugares mais populosos para onde os povos das áreas próximas pudessem ir para se instruir, não parecem ter levado em consideração as distâncias nada desprezíveis num território tão vasto como o da América portuguesa, servido, na maior parte das vezes, por caminhos mal cuidados e trilhas nas montanhas, como era o caso da Capitania de Minas Gerais. Em outros casos, as municipalidades lidavam com as dificuldades impostas pela estrutura de funcionamento do ensino régio que exigia a abertura de editais e exames para o preenchimento das cadeiras, dependendo das aprovações emanadas de Lisboa ou, conforme o caso, do Governador de Minas Gerais ou do Bispo de Mariana. O processo nem sempre era ágil, e muitas vezes as municipalidades tentavam acelerá-lo pedindo que fossem providos habitantes das próprias localidades, capazes de ocuparem os lugares de professores de Primeiras Letras ou de Gramática Latina. Muitos já exerceriam essa atividade como mestres particulares, seriam conhecidos da população, e sua nomeação apresentava-se vantajosa em relação à chegada de um completo estranho. Muitos conflitos relatados em diversos lugares eram decorrentes exatamente da desconfiança em relação a um forasteiro, sem ligações com os grupos locais, sem raízes conhecidas, e muitas vezes com perfis que atingiam os preconceitos das elites locais, como os indivíduos de baixa origem social, e os mulatos, por exemplo ${ }^{14}$.

A criação do Subsidio Literário foi justificada pela necessidade de arrecadação de recursos exclusivos para a instalação de aulas e o pagamento dos professores. Sua cobrança estaria a cargo do poder municipal, mas sob supervisão e controle dos poderes de justiça de cada comarca, em todo o Império ${ }^{15}$. Isso significa que as câmaras teriam algumas obrigações mas pouca autonomia em relação a este assunto. A cobrança do Subsidio Literário não tardou a ser iniciada mas nem sempre era seguida da instalação das aulas, o que deu ensejo a uma das queixas mais comuns das populações, enviadas aos poderes centrais por meio das câmaras municipais, e na Capitania de Minas Gerais a situação expressava suas singulares condições. Na segunda metade do século XVIII a economia mineradora já dava sinais de declínio devido ao esgotamento considerável das lavras. A introdução de um novo tributo foi vista como mais uma oneração aos povos da Capitania, ainda mais quando ocorria sem a efetivação da razão de sua criação. Esse seria, assim, o ponto central denunciado pelas câmaras na expressiva produção de requerimentos e

\footnotetext{
${ }^{14}$ Ver: Thais Nívia de Lima e Fonseca, "As câmaras e o ensino régio na América portuguesa", Revista Brasileira da História, v.33, n.66 (2013): 229-246.

${ }^{15}$ Carta de Lei de 10 de novembro de 1772, disponível em http://www.governodosoutros.ics.ul.pt/
} 
petições enviadas tanto aos governadores quanto ao Conselho Ultramarino, reivindicando ora a dispensa do pagamento, ora a nomeação de professores em troca dele.

Esses foram os argumentos utilizados numa representação da Câmara de Vila Nova da Rainha, em 1777, por meio da qual «os povos daquele termo» se queixavam do peso que suportavam pagando o Subsídio Literário numa conjuntura economicamente desfavorável sem que tivessem o benefício de um professor de Latim. Diziam que «tendo-se satisfeito a esta Real Ordem, se não seguiu o efeito da sua imposição", e por isso pediam serem dispensados do pagamento do tributo sugerindo que, na verdade, não precisariam do referido mestre, pois aqueles que quisessem instruir-se no Latim, poderiam ir ao Seminário de Mariana, que costumava receber, também, os estudantes que não pretendiam entrar para o estado sacerdotal. A representação da Câmara de Vila Nova da Rainha foi analisada pela Real Fazenda e pelo Conselho Ultramarino, que concordaram nos termos da recomendação feita por eles à Coroa:

\begin{abstract}
Que esta e outras câmaras do Brasil justamente se queixam de estarem pagando o Subsídio Literário, sem se lhes mandarem os Mestres necessários, e que estavam determinados para os seus distritos; e faltando o fim para que se introduziu esta contribuição, e sem se satisfazer as condições com que se impôs, deve necessariamente julgar-se injusta; nestes termos seria justo se representasse a Vossa Majestade esta conta, para que, ou na consideração de se não ter verificado no Brasil a introdução dos Estudos para que se impôs o Subsídio Literário, mande levantar a sua cobrança naquele Estado, como tem por mais conforme a sua Justiça, e a compaixão que merecem aqueles Povos nas circunstancias presentes; ou quando assim não seja servida ordene à Mesa Censória lhe consulte os Mestres que devem ir para o Brasil $^{16}$.
\end{abstract}

É certo que a Coroa não dispensou ninguém do pagamento do Subsídio e os povos das Minas continuaram a ter essa obrigação. A população de Vila Nova da Rainha não desistiu das queixas, mas os seus humores em relação ao ensino régio e ao tributo oscilaram ao longo do tempo, conforme outras petições elaboradas no início do século $\mathrm{XIX}$, em torno dos mesmos temas, mas com expectativas diferentes. A alternativa do estudo do Latim no Seminário de Mariana já não se apresentava. Na verdade, nunca passara de um argumento, pois na prática seria viável apenas para pessoas mais abastadas, com recursos suficientes para se manterem naquela cidade episcopal, distante cerca de 105 $\mathrm{km}^{17}$. Na década de 1780 já havia uma aula régia de Gramática Latina na Vila de Sabará, distante cerca de $37 \mathrm{~km}$, ou seja, um dia de viagem, o que já foi considerado muito numa representação que a mesma Câmara de Vila Nova da Rainha enviou em 1806 ao Governador da Capitania, solicitando a nomeação de um professor daquela cadeira. Argumentavam que o montante do Subsídio Literário arrecadado pela Câmara da Vila no ano anterior era vultoso, cerca de um conto e trezentos mil réis, mas a localidade continuava sem um

\footnotetext{
${ }^{16}$ Consulta do Conselho Ultramarino sobre a representação que fizeram os oficiais da Câmara de Vila Nova da Rainha, em 12 de setembro de 1778, Arquivo Histórico Ultramarino/Projeto Resgate, Capitania de Minas Gerais, Cx. 113-Doc. 32. Os trechos dos documentos transcritos neste artigo tiveram sua ortografia atualizada, a fim de facilitar a leitura. As marcas gramaticais - concordância e pontuação - foram mantidas conforme os originais.

${ }_{17}$ Para percorrer essa distância, na época, sería necessário em média dois ou três dias a cavalo, ou mais, dependendo das condições dos caminhos.
} 
professor régio efetivo de Gramática Latina, ao contrário da Vila de Sabará. O prejuízo era evidente:

Pelos obstáculos incômodos, porém, que resultam aos Pais de mandar seus filhos aprender mais longe aquela língua ficam estes muitas vezes sepultados na ignorância, perdendo-se sujeitos, que podiam ser uteis ao Estado. [...] e que o mesmo rendimento chega nesta Vila para haver um Mestre Latino, por estes motivos rogamos a Vossa Excelência queira dignar-se de ser-nos propício, e deferir favorável a nossa súplica, por parecer justo que a mocidade beba na fonte onde borbulham as águas; uma vez que Sua Alteza Real deixa a arbítrio de Vossa Excelência uma distribuição tão necessária ao Bem público ${ }^{18}$.

Na mesma representação, a municipalidade pedia a efetivação de Antonio José Pinheiro, morador da Vila, e que já ministrava aulas de Latim na qualidade de substituto, e para quem se requeria a provisão régia definitiva. Não há registros desse professor como efetivo, e em 1817 o problema ainda persistia. Em nova petição, a Câmara de Vila Nova da Rainha lembrava as obrigações mútuas entre o soberano e seus súditos, e os efeitos nocivos quando apenas uma das partes as cumpria:

\begin{abstract}
A Mão Real do Nosso Augusto Soberano estabeleceu Leis, para que todos estes Reinos, e Conquistas houvessem Mestres das primeiras Letras e Gramática Latina para instrução da Mocidade; taxou-lhes ordenados, e Ramos de Rendas Reais, pelos quais fossem pagos. Este Termo desde 0 ano de 1774 em que foi estabelecida esta sábia, e muito respeitável Lei, tem pago avultada soma de dinheiro de Subsídio Literário, como se vê das coletas inteiradas, e escrituradas nos Livros desta Câmara: e os Povos deste Termo tendo concorrido com os pagamentos do mesmo Subsídio, se não tem conseguido o bem para que ele foi dirigido; porque, sendo passados 43 anos da data da dita Lei, até o presente, neste tempo somente houve um Mestre de Gramática que pouco tempo serviu o seu emprego, do que tem resultado grave prejuízo à Mocidade e ao Estado ${ }^{19}$.
\end{abstract}

Numa estrutura evidentemente marcada pela força do poder central, as municipalidades tinham poucas chances de alterar o curso de determinadas políticas, especialmente quando se tratava de questões relativas à cobrança de impostos, vitais para a sustentação da economia e do Estado. Restava, então, construir estratégias de adaptação às situações desfavoráveis sem confrontar diretamente as decisões régias, procurando a negociação, conforme pode-se deduzir por essa sequência de comunicações entre a Vila Nova da Rainha e as autoridades centrais. De um pedido inicial para serem liberados do tributo, os povos da Vila finalmente tentavam negociar o cumprimento literal da lei, pedindo pelos professores necessários para compensar o pagamento do imposto. Mas não se pode ignorar também que a elaboração argumentativa acabava por incorporar, ao longo do tempo, a necessidade efetiva das aulas régias para a mocidade local. No caso analisado, um período de quase meio século em que se viam aumentar o número de cadeiras e de seus respecti-

\footnotetext{
${ }^{18}$ Representação que fazem os oficiais da Vila Nova da Rainha do Caeté, pedindo a criação de uma cadeira de Gramática Latina, Arquivo Público Mineiro/Secretaria de Governo da Capitania, 17 de outubro de 1806, SGCx.68-Doc.14.

${ }_{19}$ Petição que fazem os oficiais da Câmara, solicitando que seja nomeado um mestre, Arquivo Público Mineiro/ Secretaria de Governo da Capitania, 22 de maio de 1817, SG-Cx.101-Doc.72. Os oficiais camarários, nesta petição, referiam-se, provavelmente, ao professor régio Antonio Gonçalves Gomide, que ocupou a cadeira de Gramática Latina da Vila entre 1792 e 1801.
} 
vos professores em diversas regiões, a comparação entre as localidades mais importantes acabava inevitável. Tratava-se, muitas vezes, de rivalidades locais, entre vilas situadas a pequena distância uma da outra, e que mediam não apenas sua parcela de contribuição para o erário régio, como também os elementos civilizacionais que conseguiam conquistar. E a presença do ensino estatal era certamente um desses elementos.

Havia outras atribuições a cargo das câmaras quanto ao funcionamento cotidiano do ensino régio, embora não implicassem em poderes decisórios: o registro das provisões e da posse dos professores régios nas cadeiras existentes em sua área de jurisdição, e a concessão de atestados comprobatórios da frequência e atividades dos professores, sem os quais os ordenados não seria pagos pelas Juntas da Real Fazenda, o que constituía uma função fiscalizadora, além de manterem suas funções como intermediárias ocasionais entre a população e a Coroa ${ }^{20}$.

É importante ter conta que, apesar da diminuição sensível da autonomia das câmaras municipais no processo de centralização do poder a partir da política pombalina, as atribuições mantidas sob a sua responsabilidade mantiveram-nas no centro dos conflitos locais, pois mantiveram seu papel de intermediárias entre as populações locais e as instâncias superiores da hierarquia administrativa do Império. Para muitas dessas municipalidades, 0 atendimento a seus pedidos pelas aulas não estava fundamentado, apenas, nos interesses materiais e legais, na satisfação da contrapartida pelo pagamento dos tributos e na observância da lei também por parte da Coroa. A chegada das aulas régias tinha sua face simbólica, pois representava a presença da civilização, traço distintivo para uma sociedade que, à sua maneira, procurava cercar-se dos elementos que a afastariam das supostas marcas da barbárie.

Na segunda metade do século XVIII, com o cenário urbano já bastante consolidado em relação às décadas anteriores, as elites locais se empenhavam na construção dessa civilidade: reunidos nas associações religiosas leigas, erigiam templos dedicados às suas devoções nos quais trabalharam alguns dos mais notáveis artistas da época; em algumas vilas realizavam-se apresentações teatrais; em praticamente todas executavam-se peças musicais compostas por artistas locais inspirados pelos mestres europeus; organizavam e participavam das festividades religiosas e políticas; enviavam seus jovens para os estudos superiores em Coimbra; adquiriam, mesmo que em níveis relativamente modestos, bens de luxo como prataria, porcelanas e jóias. Bens que evocavam um ideal de civilização numa sociedade que adquiria, no entanto, escravos. Numa capitania que não vivenciou a presença das instituições educacionais das ordens religiosas, e além do Seminário de Mariana (fundado em 1750) só contava com o recurso aos mestres particulares, o advento do ensino régio foi sendo recebido aos poucos como sinal de civilização. A intenção de obtê-la apresentava-se, em muitos casos, na busca pelo alinhamento com os princípios civilizatórios presentes no discurso e nas práticas da monarquia portuguesa, e que eram utilizados com frequência na escrita produzida pelos agentes mais diretamente envolvidos

${ }^{20}$ Ver: Fonseca, "As câmaras e o ensino régio na América portuguesa". 
com a instrução no âmbito das municipalidades, principalmente os integrantes das câmaras e os professores ou candidatos ao cargo.

A pretensão de uma sociedade civilizada, privilegiadamente branca, passava, entre outras coisas, pela preservação dos princípios morais e religiosos. Numa petição dos oficiais da Câmara da Vila de Barbacena, em 1815, ficava clara a tentativa de orientar a nomeação de um professor régio conforme as expectativas dos grupos dominantes locais, e que podem ser associadas àquelas pretensões civilizacionais que o ensino régio poderia proporcionar. Na petição enviada ao governador, os oficiais camarários afirmavam que

\begin{abstract}
Tendo este Termo contribuído sempre, com os Subsídios Literários aplicados para a instrução da mocidade, vivemos na infelicidade de não haver nesta Vila um Mestre Régio, nem ao menos das primeiras letras, e sendo este objeto da maior necessidade vamos a rogar a Vossa Excelência, que em benefício da instrução da mesma mocidade nos faça a graça de criar um Mestre Régio das primeiras Letras nesta Vila, o qual apresentamos a Vossa Excelência na pessoa do Alferes José Simpliciano de Souza Barreto, por ser morador nesta Vila, homem branco, casado, e muito hábil para semelhante instrução. Vila de Barbacena em Câmara de 25 de Fevereiro de $1815^{21}$.
\end{abstract}

A indicação do Alferes ao cargo de professor demonstra os aspectos que constituíam preocupações centrais das elites locais, representadas pelas câmaras municipais. A chegada de um professor régio estranho à comunidade e às suas redes de sociabilidades poderia evocar diversas ameaças, reais ou imaginárias, caso fosse alguém de comportamento suspeito, origem social desconhecida, ou mesmo um indivíduo não branco. 0 casamento, visto desde os primeiros anos da constituição da Capitania como um meio de controle social e de construção de uma sociedade civilizada, era indicado como um valor e uma referência para o candidato a professor régio da Vila, e que além dessas qualidades, seria também um integrante das forças militares locais e, portanto, da estrutura de poder.

A chamada administração periférica atuou de maneira visível no sentido de valorizar as localidades perante o poder central, fossem vilas ou arraiais, e o ensino régio tornouse, entre outras coisas, um dos símbolos dessa valorização e da sua legitimação como partes importantes dos domínios portugueses. Além das câmaras, os poderes de justiça nas comarcas - ouvidores e corregedores - indicados como responsáveis pela verificação dos vencimentos dos professores, se envolviam nos assuntos cotidianos da instrução, e algumas vezes apareciam como determinantes na tomada de decisões por parte da Coroa, em atendimento às especificidades locais. $O$ status jurídico-administrativo das localidades nem sempre era o fator determinante para as decisões favoráveis à instalação de aulas régias. Muitos arraiais, com população expressiva, eram contemplados, com 0 aval das vilas às quais estavam ligados.

Um caso representativo estendeu-se por vários anos fazendo com que se misturassem as reivindicações do Arraial de Campanha do Rio Verde para sua elevação à condição de vila, e as demandas pela instalação de uma cadeira régia de Gramática Latina naquela lo-

${ }^{21}$ Petição que fazem os oficiais da Câmara. Arquivo Público Mineiro/Secretaria de Governo da Capitania, Cx.93Doc.32. 
calidade. O Arraial vinha reivindicando a alteração de seus status desde o final de década de 1780, alegando ter população e recursos econômicos suficientes para se desligar da Vila de São João del Rei, cabeça da Comarca do Rio das Mortes. A exploração do ouro, a produção agrícola, a considerável distância da sede da Comarca $^{22}$ e, evidentemente, o pagamento dos impostos, eram elementos que, somados à existência de um território considerável e uma população representativa, justificariam sua elevação à condição de vila com câmara própria. Isso certamente teria relação com as pretensões políticas dos grupos privilegiados locais, desejosos da ocupação de lugares de maior distinção ${ }^{23}$. Mas chama a atenção, também, o lugar que o ensino régio passaria a ocupar neste processo, sendo adicionado ao rol de argumentos que dariam ao Arraial as qualidades necessárias para ter promovido o seu status jurídico-administrativo.

Desde 0 ano de 1789, os moradores do Arraial de Campanha do Rio Verde solicitavam à Coroa a mercê de sua elevação à condição de vila, e as demandas pela instalação de uma aula régia de Gramática Latina juntaram-se àqueles pedidos, usando pelo menos dois dos mesmos argumentos: que a localidade já era populosa o suficiente, e que a distância entre ela e a sede da Comarca e mesmo de outras localidades importantes seria um dificultador para as necessidades locais, sobretudo dos assuntos de justiça, e do acesso à instrução dos jovens. Professores particulares já atuavam no Arraial, mas reivindicavase a criação de aulas régias com professores pagos pelo Subsídio Literário. Afinal, como ocorria com muitos outros arraiais, eles também pagavam o tributo, recolhido pela Câmara de São João del Rei.

O entrelaçamento entre esses dois tipos de demanda fica evidente no envolvimento do Padre Francisco José Pereira de Sampaio, que solicitava o emprego de professor de Gramática Latina em requerimentos enviados ao Conselho Ultramarino em 1790. Ele já tinha sido aprovado em exame pela Real Mesa Censória em 1787, e ensinava como substituto na Vila de Pitangui, onde ficou por um ano. Mas desejava ensinar «na Campanha do Rio Verde, Comarca do Rio das Mortes de Minas Gerais por ser ali necessário um Mestre» e por isso recorria à Coroa em virtude de haver ali «grande população [...] que excede em número de mais de quatorze mil e oitocentas pessoas, e os Mestres de Latinidade the ficam um em distância de quase 30 léguas, e outro na de 70 " ${ }^{24}$, e a fim de reforçar seus pedidos, enviou documentos emitidos pelas autoridades eclesiásticas locais que atestavam a densidade populacional do arraial. O vigário colado da Freguesia de Santo Antonio da Campanha do Rio Verde, atestou haver quatorze mil oitocentos e trinta e quatro pessoas no Arraial e nas povoações circunvizinhas, e não havia em nenhuma delas mestre de Gramática Latina, somente

\footnotetext{
${ }^{22}$ Cerca de $200 \mathrm{~km}$ separam as duas localidades.

${ }^{23}$ Requerimento dos moradores do continente e Campanha do Rio Verde. Arquivo Histórico Ultramarino/Projeto Resgate, Capitania de Minas Gerais, Cx.131-Doc.37. Requerimento dos moradores do continente e Campanha do Rio Verde. Arquivo Histórico Ultramarino/Projeto Resgate, Capitania de Minas Gerais, Cx.131-Doc.38.

${ }^{24}$ Requerimento de Francisco José de Sampaio, Arquivo Histórico Ultramarino/Projeto Resgate, Capitania de Minas Gerais, Cx.134-Doc.1.
} 
na Vila de São João d’El Rei que dista desta freguesia 30 léguas, e em São Paulo que são 70 léguas desta freguesia; e aquele que quer seguir estudos ou vai a São Paulo, ou a São João d’El Rei se podem seus pais suprir para estas despesas ficando os pobres sem se poderem habilitar para irem a partes tão remotas. ${ }^{25}$.

Também o vigário da vara da mesma freguesia atestou que naquela localidade não havia professor de Gramática Latina,

o que se faz muito preciso, e necessário para instrução da mocidade, atendendo a que o Professor Régio mais vizinho dista vinte e oito léguas, para cuja distancia se não se [...] os Pais de famílias a mandar seus filhos de dez e doze anos e expô-los à prevaricação e libertinagem ${ }^{26}$.

Respondendo às ordens da Rainha D. Maria I para que enviasse os dados necessários a uma tomada de decisão acerca do requerimento do Padre Francisco, o Corregedor da Comarca do Rio das Mortes informava que

\begin{abstract}
A Campanha do Rio Verde não é Vila: é um Arraial do Termo desta de São João d’El Rei, cabeça da Comarca do Rio das Mortes; por cuja Câmara e Governança é eleito o Juiz Ordinário, que tem para os negócios forenses somente, criado em consideração a ser distante daqui vinte e seis ou vinte e oito léguas. Pela Câmara pois de São João d’El Rei é arrecadado o Subsídio Literário daquele Arraial e Julgado, sem distinção alguma, e como um todo de todo o Termo: de sorte que se não pode neste ponto fazer um cálculo relativo. [...] Quanto à qualidade e estado da Campanha, é este Arraial pela sua população, e relativamente ao país, grande; e rico por algumas boas lavras, que tem, e principalmente pelas de São Gonçalo da Campanha, outro Arraial de sua freguesia, distante quatro léguas. Pelo que, se da Intenção de Vossa Majestade é aumentar o número das escolas de Latim, e criá-las para Julgados e Arraiais, como já foi servida criar uma para o Arraial de Guarapiranga do Termo de Mariana, e outra para o Julgado do Paracatu, do de Sabará: sem dúvida pode merecer a atenção de Vossa Majestade para semelhante fim o da Campanha do Rio Verde, onde pretende ser Professor o Suplicante Pe. Francisco José de Sampaio. Para informação de cujo requerimento ponho na Presença de Vossa Majestade estas observações, cumprindo assim com a Ordem, que em Provisão de 3 de novembro do ano passado foi Vossa Majestade servida mandar-me expedir. São João d'el Rei, 12 de julho de 1794. Luis Antonio Bernardes de Carvalho27.
\end{abstract}

Os moradores de Campanha do Rio Verde continuaram a reivindicar a promoção de seus status jurídico-administrativo e, a despeito das resistências da Câmara de São João del Rei, ela foi finalmente elevada à categoria de Vila em outubro de 1798 , tendo recebido sua aula régia de Gramática Latina nos primeiros anos do século XIX, ocupada, finalmente, pelo Padre Francisco José de Sampaio.

A disputa pela distinção e pelos privilégios advindos com a instalação de uma vila e sua câmara envolviam, entre outras coisas, a disputa pela distribuição dos recursos do Subsídio Literário, sobretudo quando envolviam vilas muito próximas geograficamente. Desde a sua criação em 1718, a Vila de São José, no Rio das Mortes, enfrentou divergências com a Vila de São João del Rei, criada em 1713 e cabeça da Comarca, que logo

\footnotetext{
${ }^{25}$ Ibídem.

${ }^{26}$ Ibídem.

${ }^{27}$ Carta de Luis Antonio Bernardes de Carvalho, Arquivo Histórico Ultramarino/Projeto Resgate, Capitania de Minas Gerais, Cx.139-Doc.26.
} 
protestou por meio de sua câmara municipal pela instalação de uma vila a tão pequena distância ${ }^{28}$. Entre outros tantos temas de conflitos, a criação e funcionamento de cadeiras de Gramática Latina e Primeiras Letras nas duas vilas geraram insatisfações dos dois lados, pois colocava-se em questão a distribuição do Subsídio Literário na mesma área geográfica, e a mobilidade de alguns professores, que residiam numa vila e ensinavam na outra. Isso poderia ser interpretado como desvio indevido do tributo por meio do pagamento do professor régio.

A Vila de São José parecia ser particularmente afetada por sua situação geográfica, colocando-a em meio a disputas não apenas com a mais poderosa Vila de São João del Rei, sua vizinha, mas com outras localidades na mesma região que, segundo seus moradores, foram tirando dela recursos e prestígio. Entre 1789 e 1791 parte do território que integrava a área sob jurisdição da Vila de São José foi desmembrada em três, onde foram criadas novas vilas com suas próprias câmaras: São Bento do Tamanduá, Queluz e Barbacena. A criação destas vilas, durante o governo do Visconde de Barbacena na Capitania de Minas Gerais, está associada às medidas de contenção tomadas por este governador como decorrência da conspiração de 1789 conhecida como Inconfidência Mineira, que envolveu grupos importantes das elites de várias partes da Capitania e foi duramente reprimida pela Coroa. A Comarca do Rio das Mortes foi tida como particularmente insurreta, e vários dos conspiradores eram habitantes dela e influentes nas Vilas de São João e de São José. Com o intuito de neutralizar as insatisfações desses grupos poderosos locais, o Governador não somente diminuiu a influência da Vila de São José como distribuiu benesses a eles por meio do estabelecimento de novas vilas, que vinham acompanhadas de novos cargos, posições e privilégios.

Passados poucos anos, a câmara expressou sua insatisfação com os efeitos dessas medidas, e procurava sensibilizar a Coroa relatando os graves problemas que enfrentava devido às perdas decorrentes daquela divisão de poderes e territórios. Recuperando a memória dos serviços prestados à Coroa desde a criação da Vila - sem mencionar, evidentemente, seu envolvimento na conspiração - os representantes da câmara protestavam contra a elevação à vila de três inexpressivos arraiais da região e apontavam os grandes prejuízos materiais e políticos que São José havia sofrido ${ }^{29}$. A divisão operada impactou, certamente, a arrecadação dos tributos, entre os quais o Subsídio Literário, e logo a vila ficaria vários anos com a cadeira régia de Gramática Latina vaga e com a de Primeiras Letras ocupada de maneira instável. Talvez não por acaso, fixaram-se as de Queluz e de São Bento do Tamanduá, pelo menos.

As implicações políticas no processo de implantação e funcionamento do ensino régio na América portuguesa, em conjunturas específicas nas diferentes capitanias do Brasil, são uma frente ainda por desbravar nos estudos sobre as reformas pombalinas da educação e seus efeitos. A situação da Vila de São José do Rio das Mortes, brevemente comentada

\footnotetext{
${ }^{28}$ A distância entre as duas é de cerca de $15 \mathrm{~km}$, o que corresponderia a aproximadamente 2,5 léguas.

${ }^{29}$ Representação da Câmara da Vila de São José del Rei ao Governador, Arquivo Público Mineiro/Secretaria de Governo da Capitania, SG-Cx.39-Doc.06.
} 
aqui, indica um importante caminho analítico a ser considerado no movimento de criação das aulas régias, para além de um conjunto de ações de Estado, derivadas unicamente de sua visão, naquele momento, marcada pela influência de ideias ilustradas. Se é possível e necessário associar esse movimento às intenções modernizadoras da Coroa portuguesa, e que significavam a secularização progressiva da administração do Império, é fundamental considerar que, ao menos para os domínios americanos, ele era também parte do processo de sedimentação do poder régio nesses territórios e instrumento de negociação com as elites locais. A presença de professores régios em número expressivo de localidades significaria levar porções da administração e de seu controle para lugares onde essa estrutura não era ainda tão presente e permanente, além de fortalecer os liames entre eles e as vilas mais importantes. Afinal, elas, por meio de suas câmaras, tornavam-se responsáveis por parte desse controle graças às suas obrigações para com os professores régios, funcionários do Estado. Por ali, portanto, passariam as questões relacionadas à administração geral, à cobrança e à distribuição dos tributos.

Esse processo, além de ser justificado contemporaneamente por sua capacidade de levar a civilização, os bons costumes e a ordem para o máximo possível de lugares, contribuiu para aumentar progressivamente a visibilidade da instrução pública, construindo aos poucos a sua representação como um valor social e cultural, como um instrumento da elaboração de distinção, em diferentes níveis sociais. 0 ensino régio na América portuguesa guarda particularidades, sendo uma delas a sua opacidade material, pois as aulas não tinham local certo e específico para acontecer, sendo tão móveis quanto o eram seus professores. Apesar disso, ele foi se tornando parte integrante do cenário urbano, nas vilas e nos arraiais, e indicativo, para parcelas da população, de pertencimento ao Império não apenas como vassalos contribuintes mas também como destinatários de um «serviço» que os beneficiaria individualmente. Era ainda um meio de obtenção de distinção para os estudantes que frequentariam as aulas, mas sobretudo para os professores, que teriam nos cargos de funcionários da Coroa, uma oportunidade de construção de um lugar social mais visível e valorizado.

\section{Bibliografia}

"Dados sobre a instrucção pública, 1814", Revista do Arquivo Público Mineiro, v.VII, II-IV (1902): 989.

Adão, Áurea. Estado absoluto e ensino das primeiras letras. As escolas régias, 1772-1794. Lisboa: Fundação Calouste Gulbenkian, 1997.

Andrade, Francisco Eduardo de. A invenção das Minas Gerais. Empresas, descobrimentos e entradas nos sertões do ouro na América portuguesa. Belo Horizonte: Autêntica, 2008.

Araújo Silva, José Carlos de. As aulas régias na Capitania da Bahia (1759-1827): pensamento, vida e trabalho de "nobres" professores". Tese de Doutoramento, Universidade Federal do Rio Grande do Norte, 2006.

Araújo, Ana Cristina. A cultura das luzes em Portugal. Lisboa: Livros Horizonte, 2003. 
Araújo, Ana Cristina. O Marquês de Pombal e a Universidade. Coimbra: Imprensa da Universidade de Coimbra, 2014.

Azevedo, Fernando de. A cultura brasileira. Brasília: Editora da Universidade de Brasília, 1963.

Banha de Andrade, António Alberto. A reforma pombalina dos estudos secundários no Brasil. São Paulo: Saraiva/Edusp, 1978.

Boto, Carlota. Instrução pública e projeto civilizador. O século XVIII como intérprete da ciência, da infância e da escola. São Paulo: Editora Unesp, 2017.

Carvalho, Rómulo de. História do Ensino em Portugal. Lisboa: Fundação Calouste Gulbenkian, 2008.

Damasceno Fonseca, Cláudia. Arraiais e vilas d’el Rei. Espaço e poder nas Minas setecentistas. Belo Horizonte: Editora UFMG, 2011.

Fragoso, Myriam Xavier. O ensino régio na Capitania de São Paulo, 1759-1801 Tese de Doutoramento, Universidade de São Paulo, 1972.

Lima e Fonseca, Thais Nívia de. "As câmaras e o ensino régio na América portuguesa". Revista Brasileira da História, 66, v.33, (2013): 229-246.

Maxwell, Kenneth. Marquês de Pombal, paradoxo do Iluminismo. Rio de Janeiro: Paz e Terra, 1996.

Mello e Souza, Laura de. Desclassificados do ouro. A pobreza mineira no século XVIII Rio de Janeiro: Graal, 1982.

Mello e Souza, Laura de. O sol e a sombra. Política e administração na América portuguesa do século XVIII. São Paulo: Companhia das Letras, 2006.

Menezes e Oliveira, Pablo. "Entre cartas, panos, tintas e coração: representação e prática política das Casas de Câmara na Capitania de Minas Gerais, século XVIII". Em As Minas e o Império: dinâmicas locais e projetos coloniais portugueses, org. Adriano Toledo Paiva e Pablo Menezes e Oliveira, 161.Belo Horizonte: Fino Traço, 2013.

Paulo da Silva, Adriana Maria. Processos de construção das práticas de escolarização em Pernambuco em fins do século XVIII e primeira metade do século XIX. Recife: Editora da UFPE, 2008.

Ramos de Carvalho, Laerte. As reformas pombalinas da instrução pública. São Paulo: Saraiva/Edusp, 1978.

Rolo Fachada Levy Cardoso, Tereza Maria. As luzes da educação: fundamentos, raízes históricas e prática das aulas régias no Rio de Janeiro, 1759-1834. Bragança Paulista, SP: Editora da Universidade São Francisco, 2002.

Silveira, Marco Antonio. O universo do indistinto. Estado e sociedade nas Minas setecentistas, 1735-1808. São Paulo: Hucitec, 1997. 
Souza Dourado, Nileide. Práticas Educativas Culturais e Escolarização na capitania de Mato Grosso, 1748-1822.Tese de Doutoramento, Universidade Federal de Mato Grosso, 2014.

Fontes documentais:

Alvará de Regulamento dos Estudos Menores, de 28 de junho de 1759, disponível em http://www.governodosoutros.ics.ul.pt/

Alvará de 4 de Junho de 1771, disponível em http://www.governodosoutros.ics.ul.pt/

Arquivo Público Mineiro/Secretaria de Governo da Capitania/Seção Colonial. SC-394, fls. 47-47a.

Carta de Lei de 10 de Novembro de 1772 e Instrucções de 4 de Setembro de 1773. Disponível em http://www.governodosoutros.ics.ul.pt/

Carta de Lei de 10 de novembro de 1772, disponível em http://www.governodosoutros. ics.ul.pt/

Carta de Luis Antonio Bernardes de Carvalho, Arquivo Histórico Ultramarino/Projeto Resgate, Capitania de Minas Gerais, Cx.139-Doc.26.

Consulta do Conselho Ultramarino sobre a representação que fizeram os oficiais da Câmara de Vila Nova da Rainha, em 12 de setembro de 1778, Arquivo Histórico Ultramarino/Projeto Resgate, Capitania de Minas Gerais, Cx. 113-Doc.

Petição que fazem os oficiais da Câmara, solicitando que seja nomeado um mestre, Arquivo Público Mineiro/Secretaria de Governo da Capitania, 22 de maio de 1817, SG-Cx.101-Doc.72.

Petição que fazem os oficiais da Câmara. Arquivo Público Mineiro/Secretaria de Governo da Capitania, Cx.93-Doc.32.

Representação que fazem os oficiais da Vila Nova da Rainha do Caeté, pedindo a criação de uma cadeira de Gramática Latina, Arquivo Público Mineiro/Secretaria de Governo da Capitania, 17 de outubro de 1806, SG-Cx.68-Doc.14.

Representação da Câmara da Vila de São José del Rei ao Governador, Arquivo Público Mineiro/Secretaria de Governo da Capitania, SG-Cx.39-Doc.06.

Requerimento dos moradores do continente e Campanha do Rio Verde. Arquivo Histórico Ultramarino/Projeto Resgate, Capitania de Minas Gerais, Cx.131-Doc.37.

Requerimento dos moradores do continente e Campanha do Rio Verde. Arquivo Histórico Ultramarino/Projeto Resgate, Capitania de Minas Gerais, Cx.131-Doc.38.

Requerimento de Francisco José de Sampaio, Arquivo Histórico Ultramarino/Projeto Resgate, Capitania de Minas Gerais, Cx.134-Doc.1. 